\title{
PENGARUH RASIO KEUANGAN TERHADAP HARGA SAHAM PADA PERUSAHAAN MANUFAKTUR SEKTOR INDUSTRI BARANG KONSUMSI YANG TERDAFTAR DI BURSA EFEK INDONESIA PERIODE TAHUN 2013-2016
}

\author{
Ni Luh Dewi Martiani \\ Jurusan Pendidikan Ekonomi, Fakultas Ekonomi \\ Universitas Pendidikan Ganesha \\ Singaraja, Indonesia \\ e-mail: martiani.dewi@yahoo.com
}

\begin{abstract}
Abstrak
Penelitian ini bertujuan untuk mengetahui pengaruh secara parsial current ratio, dept to equity ratio, return on equity, net profit margin terhadap harga saham dan pengaruh secara simultan antara current ratio, dept to equity ratio, return on equity ratio, net profit margin terhadap harga saham. Jenis penelitian yang digunakan adalah penelitian kausal dengan pendekatan kuantitatif. Data dikumpulkan menggunakan metode dokumentasi.Teknik analisis data yang digunakan yaitu uji regresi linier berganda. Hasil penelitian menunjukkan bahwa secara parsial current ratio berpengaruh positif dan signifikan terhadap harga saham, dept to equity ratio berpengaruh positif dan signifikan terhadap harga saham, return on equity berpengaruh positif dan signifikan terhadap harga saham, net profit margin berpengaruh positif dan signifikan terhadap harga saham, dan secara simultan current ratio, dept to equity, return on equity dan net profit margin berpengaruh terhadap harga saham.
\end{abstract}

Kata kunci: current ratio, dept to equity, return on equity, net profit margin, harga saham

\begin{abstract}
This study aimed at investigating the partial effect of current ratio, dept to equity ratio, return on equity ratio, net profit margin on stock prices well as and the simultaneous effect of current ratio, dept to equity ratio, return on equity ratio, and net profit margin on stock prices. This study was a causal research with quantitative approach. The data were collected by using documentation method. The data analysis was done by using multiple regression analysis. The result of the study shows that partially, current ratio give positive and significant effect on stock prices, dept to equity ratio give positive and significant effect on stock prices, net profit margin give positive and significant effect on stock prices, net profit margin give positive and significant effect on stock prices, and simultaneously, current ratio, dept to equity ratio, return on equity ratio, and net profit margin give significant effect on stock prices.
\end{abstract}

Keywords: current ratio, dept to equity, return on equity, net profit margin, stock prices.

\section{PENDAHULUAN}

Dalam mencapai tujuan

pembangunan Indonesia untuk meningkatkan masyarakat adil dan makmur, aspek yang paling ditingkatkan adalah dalam bidang ekonomi. Dengan adanya berbagai perusahaan yang go public memperlihatkan perekonomian bangsa berkembang cukup signifikan.
Dalam menghadapi persaingan perusahaan harus mampu bertahan hidup dab memperhatikan hal-hal yang yang fundamental. Menurut Kasmir (2012:184), "pasar modal merupakan suatu tempat bertemunya para penjual dan pembeli untuk melakukan transaksi dalam rangka memperoleh modal'. Dalam aktivitasnya, perusahaan- 
p-ISSN : 2599-1418

e-ISSN : 2599-1426

perusahaan tersebut tidak terlepas dari interaksinya dengan berbagai elemen masyarakat sekelilingnya sebagai suatu mata rantai perilaku ekonomi, seperti stakeholder, distributor, konsumen, produsen pesaing, dan investor baik individu maupun badan usaha, serta pemerintah yang membuat kebijakan dan peraturan sebagai perannya dalam mengontrol pertumbuhan ekonomi. Menurut Husnan (2003:67), "pasar modal merupakan pasar untuk berbagai instrumen keuangan jangka panjang yang bisa diperjualbelikan, baik dalam bentuk hutang ataupun modal sendiri". Menurut Susilo (2009:21), "saham merupakan tanda penyertaan modal seseorang atau pihak (badan usaha) dalam suatu perusahaan atau perseroan terbatas". Menurut Rahmadi (2010:22), "harga saham merupakan harga yang dibentuk dari interaksi para penjual dan pembeli saham yang dilatarbelakangi pleh harapan terhadap profil perusahaan". Saham yang sudah go public sangatlah peka terhadap perubahan politik, ekonomi, moneter baik perubahan luar negeri maupun dalam negeri. Pasar modal diharapkan mampu menjadi alternatif pendanaan bagi perusahaan di Indonesia dan dapat juga dilihat sebagai alternatif dalam berinvestasi.

Perubahan tersebut dapat berdampak positif yang berarti naiknya harga saham atau berdampak negatif yang berarti turunnya sehingga memiliki tingkat resikoyang sangat tinggi. Tujuan perusahaan melakukan investasi saham adalah untuk memperoleh modal usaha yang akan digunakan untuk kegiatan operasi perusahaan. Investasi dalam bentuk saham mempunyai potensi keuntungan dan risiko yang sesuai dengan prinsip investasi. Semakin tinggi potensi keuntungan dari suatu instrimen investasi, semakin tinggi pula kemungkinan risiko yang diderita investor, demikian pula sebaliknya. Keuntungan yang diperoleh dari pemegang saham yaitu capital gains, deviden dan saham perusahaan. Aktivitas di pasar modal, harga saham merupakan faktor yang sangat penting
Jurnal Pendidikan Ekonomi Undiksha

Volume 10 No. 2 Tahun 2018

dan harus diperhatikan oleh investor dalam melakukan investasi, karena harga saham menunjukkan nilai suatu perusahaan. Semakin tinggi nilai harga saham semakin tinggi pula nilai perusahaan tersebut dan juga sebaliknya. Harga saham di bursa ditentukan oleh kekuatan pasar yang berarrti harga saham tergantung dari kekuatan permintaan dan penawaran. Kondisi permintaan atau penawaran atas harga saham yang fluktuatif tiap harinya akan membawa pola harga saham yang fluktuatif juga. Menurut Nirawati (2003:32), "pada kondisi dimana permintaan saham lebih besar, maka harga saham akan cenderung naik, sedangkan pada kondisi dimana penawaran saham lebih banyak makan harga saham akan menurun".

Perusahaan selalu berusaha untuk memaksimalkan nilai sahamnya agar banyak investor tertarik menanamkan modalnya untuk perusahaan. Menurut Kasmir (2012:185), "dalam pasar modal investor diituntut untuk dapat menguasai informasi fundamental atas sejumlah saham yang diinvestasikannya. Menurut Halim (2005:13), "dalam melakukan investasi di pasar modal para analis dan investor dapat melakukan pendekatan investasi yang secara garis besar dapat dibedakan menjadi dua pendekatan yaitu analisis teknikal dan analisis fundamental". Analisis fundamental sendiri didasarkan pada laporan keuangan perusahaan yang dapat dianalisis melalui rasio-rasio keunagan dan ukuran-ukuran lainnya seperti cash flow untuk mengukur kinerja keuangan perusahaan.

Analisis rasio keuangan dapat dibagi ke dalam tiga bentuk umum yang sering dipergunakan antara lain: rasio likuiditas, rasio solvabilitas dan rasio protabilitas. Di dalam penelitian ini variabel yang digunakan adalah variabel bebas yaitu rasio keuangan dan variabel terikat yaitu harga saham. Variabel bebas dalam penelitian ini terdiri dari current ratio, dept to equity, return on equity dan net profit margin. 
p-ISSN : 2599-1418

e-ISSN : 2599-1426
Jurnal Pendidikan Ekonomi Undiksha

Volume 10 No. 2 Tahun 2018
Menurut Kasmir (2008:140), "current ratio merupakan rasio yang bertujuan untuk mengukur kemampuan suatu perusahaan untuk memenuhi kewajiban jangka pendek dengan aktiva lancarnya. Menurut Fahmi (2001:79), "dept to equity merupakan perbandingan antara total hutang (hutang lancar dan hutang jangka panjang) dan modal yang menunjukkan kemampuan perusahaan untuk memenuhi kewajibannya dengan menngunakan modal yang ada". Menurut Harahap (2008;32), "protabilitas modal sendiri (return on equity) merupakan suatu pengukuran dari penghasilan (income) yang tersedia bagi para pemilik perusahaan (baik pemegang saham biasa maupun pemegang saham preferen) atas modal yang mereka investasikan di dalam perusahaan". Menurut Sawir (2001:23), "return on equity sebagai variabel bebas karena protabilitas modal sendiri ini memperlihatkan sejauh mana perusahaan mengelola modal sendiri (net work) secara efektif'. Menurut Husnan (2003:74), "net profit margin merupakan rasio yang dihitung dari pembagian antara laba operasi dengan penjualan". Jenis pasar modal ada empat yaitu pasar perdana, pasar sekunder, pasar ketiga dan pasar keempat.

Dalam melakukan transaksi di pasar, biasanya ada barang atau jasa yang diperjualbelikan. Begitu pula dalam pasar modal, barang yang diperjualbelikan dikenal dengan istilah instrumen pasar modal. Menurut Kasmir (2012:85), "instrumen psar modal adalah semua surat-surat berharga yang dapat diperjualbelikan kembali oleh pemiliknya, baik instrumen pasar modal bersifat kepemilikan atau bersifat utang". Adapun instrumen yang diperdagangkan adalah saham (stock), obligasi (bonds), waran, dan right issue. Pada aktivitas perdagangan saham sehari-hari, harga saham selalu mengalami fluktuasi kenaikan maupun penurunan harga saham. Menurut Gitman (2008:3), " harga saham di bursa ditentukan oleh mekanisme pasar yaitu kekuatan permintaan dan penawaran saham tersebut". Semakin banyak orang yang membeli suatu saham, maka harga saham tersebut cenderung akan bergerak naik. Demikian juga sebaliknya, semakin banyka orang yang menjual saham suatu perusahaan, maka harga saham tersebut akan bergerak turun. Menurut Kasmir (2012;15), "faktor-faktor yang mempengaruhi harga saham adalah rasio keuangan, hukum permintaan dan penawaran, tingkat suku bunga bank Indonesia, valuta asing, dana asing di bursa, indeks harga saham gabungan dan news and rumors". Menurut Alwi (2003:87), "faktor-faktor yang mempengaruhi pergerakan harga saham, antara lain faktor internal dan faktor eksternal". Dalam upaya mengembangkan bisnisnya perusahaan tentu saja membutuhkan dana yang sangat besar.

Menurut Fahmi (2001:103), "tujuan laporan keuangan adalah untuk memberikan informasi kepada pihak yang membutuhkan tentang kondisi suatu perusahaan dari sudut angkaangka dalam satuan moneter". Menurut Subramanyam (2005:56), "laporan ini menyediakan sejarah perusahaan dalam kuantitas uang". Laporan yang disediakan adalah neraca (Balance sheet), laporan laba rugi (Income statement) dan laporan arus kas. Berdasarkan konsep keuangan maka laporan keuangan sangat diperlukan untuk mengukur hasil usaha dan perkembangan perusahaan dari waktu ke waktu dan untuk mengetahui sudah sejauh mana perusahaan mencapai tujuannya. Seperti keinginan perusahaan untuk melakukan right issue yang artinya diprioritaskan kepada pemilik saham lama untuk membelinya. Sehinnga berdasarkan data laporan keuangan yang diperoleh dan disajikan oleh manajemen perusahaan akan bisa menganalisis bagaimana kondisi perusahaan serta prospek perusahaan nantinya, khusususnya dari segi kemampuan protabilitas yang akan dihasilkan. Dapat dipahami bahwa laporan keuangan sangat berguna 
p-ISSN : 2599-1418

e-ISSN : 2599-1426
Jurnal Pendidikan Ekonomi Undiksha

Volume 10 No. 2 Tahun 2018 dalam melihat kondisi suatu perusahaan. Kemajuan perekonomian suatu Negara salah satunya dapat direfeksikan oleh aktivitas pasar modal yang ada di Negara tersebut.

Seiring dengan perkembangan jaman sektor industri barang konsumsi sangat berperan penting dalam dunia industri. Hal tersebut terlihat dari meningkatnya jumlah produksi karena semakin tinggnya permintaan dari konsumen sehingga perusahaan berlomba-lomba untuk memproduksi berbagai jenis barang yang sesuai dengan keinginan konsumen saat ini. Analisis rasio keuangan merupakan alternatif untuk menguji apakah informasi keuangan bermanfaat untuk melakukan klasifikasi atau prediksi terhadap harga saham. Analisis laporan leuangan pada dasarnya ingin mengetahui apakah kondisi dan kinerja perusahaan baik. Menurut Husnan (2003:61), "ada beberapa cara yang dapat ditepuh untuk melakukan analisis laporan keuangan seperti analisis strategi bisnis (business analysis), analisis akuntansi (accounting analysis), analisis prospektif (prospective analysis) dan analisis keuangan (financial analysis). Analisis rasio keuangan didasarkan pada data keuangan historis yang tujuan utamanya memberikan suatu indikasi kinerja keuangan perusahaan pada masa yang akan datang.

Berdasarkan uraian diatas, maka penulis tertarik untuk melakukan penelitian mengenai kinerja keuangan dengan tema berbeda namun memiliki tujuan yang sama yaitu menganalisis rasio keuangan untuk menentukan besarnya harga saham pada perusahaan yang terdaftar di Bursa Efek Indonesia. Penelitian kali ini menggunkan 4 rasio keuangan, diantaranya current ratio, dept to equity, return on equity, dan net profit margin dengan judul "Pengaruh Rasio Keuangan Terhadap Harga Saham pada Perusahaan Manufaktur Sektor Industri Barang Konsumsi yang Terdaftar di Bursa Efek Indonesia Periode Tahun 2013-2016".
Perusahaan sektor industri barang konsumsi yang terdaftar (go public) di Bursa Efek Indonesia dipilih sebagai perusahaan yang diteliti dengan mempertimbangkan persaingan yang semakin kompetitif, sehingga menuntut kinerja perusahaan yang selalu prima agar unggul dalam persaingan, baik bersaing dengan perusahaan yang telah go public maupun yang belum go public. Disamping itu, industri ini menyediakan kebutuhan primer manusia sehingga tetap dapat menjadi prioritas utama konsumen meskipun kondisi perekonomian kurang mendukung. Bagaimanapun buruknya kondisi kehidupan ekonomi konsumen, mereka masih tetap membutuhkan barang konsumsi berupa makanan dan minuan untuk mempertahankan kelangsungan hidupnya.

Berdasarkan uraian diatas, maka tujuan dari penelitian ini adalah untuh mengetahui pengaruh secara parsial current ratio terhadap harga saham, pengaruh secara parsial dept to equity terhadap harga saham, pengaruh secara parsial return on equity terhadap harga saham, pengaruh secara parsial net profit margin terhadap harga saham dan pengaruh secara simultan antara rasio-rasio keuangan yang terdiri dari current ratio, dept to equity, return on equity, net profit margin terhadap harga saham pada perusahaan manufaktur yang terdaftar di Bursa Efek Indonesia tahun 2013-2016.

\section{METODE}

Penelitian ini menggunakan penelitian kausal dengan pendekatan kuantitatif. Data yang dihasilkan berupa data terkait dengan laporan keuangan yang diperoleh dari situs resmi di Bursa Efek Indonesia (BEI) periode tahu 20132016. Penelitian ini dilakukan pada perusahaan industri barang konsumsi yang terdaftar di BEI pada perusahaan manufaktur sektor industri barang konsumsi yang bertujuan untuk mengetahui current ratio, dept to equity, return on equity dan net profit margin terhadap harga saham secara parsial dan simultan. 
p-ISSN : 2599-1418

e-ISSN : 2599-1426

Subjek dalam penelitian adalah perusahaan yang tergolong dalam kelompok perusahaan manufaktur sektor industri barang konsumsi yang terdaftar di Bursa Efek Indonesia (BEI) periode 2013-2016 yang berjumlah 14 perusahaan dan objek penelitian adalah current ratio, dept to equity, return on equity, net profit margin dan harga saham.

Adapun jenis data yang digunakan dalam penelitian ini adalah data kuantitatif berupa data yang berhubungan dengan laporan keuangan yang diperoleh dari situs resmi Bursa Efek Indonesia yaitu melalui www.sahamok.com, www.idx.co.id dan www.yahoofinance.com. Data yang digunakan adalah data sekunder yang diperoleh dari Statistic Indonesia Stock Exchange (IDX) pada perusahaan sektor industri barang konsumsi periode 2013-2016.

Dokumentasi dipergunakan untuk memperoleh data laporan tahunan pada masing-masing perusahaan manufaktur sektor industri barang konsumsi untuk mengetahui rasio-rasio keuangannya selama periode 2013-2016.

Teknis analisis data yang digunakan dalam penelitian ini adalah dengan menggunakan analisis linier
Jurnal Pendidikan Ekonomi Undiksha

Volume 10 No. 2 Tahun 2018

berganda dengan menggunakan program statistic product and service solution for windows. Untuk menjawab masalah pokok apakah diantaranya current ratio, dept to equity, return on equity, net profit margin memiliki pengaruh yang signifikan terhadap harga saham secara parsial dan simultan, maka dilakukan analisis berganda. Tahap analisis statistic yang dilakukan adalah uji asumsi klasik, analisis regresi linier berganda, uji parsial (Uji t), dan uji simultan (Uji F).

\section{HASIL DAN PEMBAHASAN Hasil Penelitian}

Pengaruh current ratio terhadap harga saham pada perusahaan manufaktur sektor industri barang konsumsi yang terdaftar di Bursa efek Indonesia periode tahun 2013-2016. Untuk mengetahui pengaruh current ratio secara parsial terhadap harga saham pada perusahaan manufaktur sektor industri barang konsumsi, dilakukan analisis t-test dengan menggunakan SPSS 17.0 for windows. Hasil analisis tersebut menunjukkan bahwa pengaruh current ratio terhadap harga saham pada perusahaan manufaktur sektor industri barang konsumsi dapat dilihat pada tabel 1 berikut.

Tabel 1. Hasil Uji Signifikan Parsial (Uji t)

\begin{tabular}{cccccc}
\hline Model & \multicolumn{2}{c}{$\begin{array}{c}\text { Unstandardized } \\
\text { Coefficientd }\end{array}$} & $\begin{array}{c}\text { Standarized } \\
\text { Coefficients }\end{array}$ & T & Sig. \\
\cline { 2 - 4 } & $\mathrm{B}$ & Std. Error & Beta & & \\
\hline 1 (Constant) & -47203 & 9591 & & -4922 & 0.000 \\
$\begin{array}{c}\text { Current } \\
\text { Ratio }\end{array}$ & 14480 & 4556 & 0.347 & 3.178 & 0.003
\end{tabular}

Berdasarkan hasil analisis pada tabel 1 dapat diketahui bahwa variabel current ratio memiliki $p$-value $=$ $0,003<\alpha=0,05$ maka $\mathrm{H}_{0}=$ ditolak dan $\mathrm{H}_{\mathrm{a}}$ diterima. Dengan demikian dapat disimpulkan bahwa current ratio secara parsial memiliki pengaruh yang positif dan signifikan terhadap harga saham pada perusahaan manufaktur sektor industri barang konsumsi pada periode tahun 2013-2016. Berarti hal ini tinggi rendahnya current ratio pada suatu perusahaan dilihat dari kemampuan perusahan memenuhi jangka pendeknya.

Pengaruh dept to equity terhadap harga saham pada perusahaan manufaktur sektor industri barang konsumsi. Untuk mengetahui pengaruh debt to equity secara parsial terhadap harga saham pada perusahaan manufaktur sektor industri barang konsumsi yang terdaftar di Bursa Efek Indonesia tahun 2013-2016, dilakukan 
p-ISSN : 2599-1418

e-ISSN : 2599-1426
Jurnal Pendidikan Ekonomi Undiksha

Volume 10 No. 2 Tahun 2018 analisis t-test dengan menggunakan SPSS 17.0 for windows. Hasil analisis tersebut menunjukkan bahwa pengaruh debt to equity terhadap harga saham pada perusahaan manufaktur sektor industri barang konsumsi yang terdaftar di Bursa Efek Indonesia dapat dilihat pada tabel 2 berikut.

Tabel 2. Hasil Uji Signifikan Parsial (Uji t)

\begin{tabular}{cccccc}
\hline Model & \multicolumn{2}{c}{$\begin{array}{c}\text { Unstandardized } \\
\text { Coefficientd }\end{array}$} & $\begin{array}{c}\text { Standarized } \\
\text { Coefficients }\end{array}$ & T & Sig. \\
\cline { 2 - 4 } & B & Std. Error & Beta & & \\
\hline 1 (Constant) & -47203 & 9591 & & -4922 & 0.000 \\
$\begin{array}{c}\text { Dept to } \\
\text { equity }\end{array}$ & 313 & 3950 & 0.006 & 0.079 & 0.004 \\
\hline
\end{tabular}

Pengaruh debt to equity terhadap harga saham pada perusahaan manufaktur sektor industri barang konsumsi berdasarkan perhitungan uji $t$ pada tabel 2 menunjukkan bahwa debt to equity berpengaruh terhadap harga saham pada perusahaan manufaktur sektor industri barang konsumsi, karena variabel Debt to Equity memiliki $p$-value $=0,004<\alpha=0,05$ maka $H_{0}=$ ditolak dan $\mathrm{H}_{\mathrm{a}}$ diterima. Dengan demikian dapat disimpulkan bahwa debt to equity memiliki pengaruh yang positif dan signifikan terhadap harga saham pada perusahaan manufaktur sektor industri barang konsumsi yang terdaftar di bursa efek Indonesia periode tahun 2013-2016.

\begin{abstract}
Pengaruh return on equity terhadap harga saham pada perusahaan manufaktur sektor industri barang konsumsi yang terdaftar di Bursa Efek Indonesia tahun 2013-2016. Untuk mengetahui pengaruh retunt on equity secara parsial terhadap harga saham pada perusahaan manufaktur sektor industri barang konsumsi, dilakukan analisis t-test dengan menggunakan SPSS 17.0 for windows. Hasil analisis tersebut menunjukkan bahwa pengaruh return on equity terhadap harga saham pada perusahaan manufaktur sektor industri barang konsumsi yang terdaftar di bursa efek Indonesia periode tahun 2013-2016 dapat dilihat pada tabel 3 berikut.
\end{abstract}

Tabel 3. Hasil Uji Signifikan Parsial (Uji t)

\begin{tabular}{cccccc}
\hline Model & \multicolumn{2}{c}{$\begin{array}{c}\text { Unstandardized } \\
\text { Coefficientd }\end{array}$} & $\begin{array}{c}\text { Standarized } \\
\text { Coefficients }\end{array}$ & T & Sig. \\
\cline { 2 - 4 } & $\mathrm{B}$ & Std. Error & Beta & & \\
\hline 1 (Constant) & -47203 & 9591 & & -4922 & 0.000 \\
$\begin{array}{c}\text { Return on } \\
\text { equity }\end{array}$ & 4746 & 1648 & 0.322 & 2.879 & 0.006 \\
\hline
\end{tabular}

Pengaruh return on equity terhadap harga saham pada perusahaan manufaktur sektor industri barang konsumsi yang terdaftar di Bursa Efek Indonesia berdasarkan perhitungan uji $t$ pada tabel 3 menunjukkan bahwa return on equity berpengaruh terhadap harga saham pada perusahaan manufaktur sektor industri barang konsumsi, karena variabel Return on Equity memiliki $p$ value $=0,006<\alpha=0,05$ maka $\mathrm{H}_{0}=$ ditolak dan $\mathrm{H}_{\mathrm{a}}$ diterima. Dengan demikian dapat disimpulkan bahwa return on equity memiliki pengaruh yang positif dan signifikan terhadap harga saham pada perusahaan manufaktur sektor industri barang konsumsi.

Pengaruh net profit margin terhadap harga saham. Untuk mengetahui pengaruh net profit margin secara parsial terhadap harga saham pada perusahaan manufaktur sektor industri barang konsumsi, dilakukan analisis t-tes dengan menggunakan SPSS 17.0 for windows. Hasil analisis 
p-ISSN : 2599-1418

e-ISSN : 2599-1426
Jurnal Pendidikan Ekonomi Undiksha

Volume 10 No. 2 Tahun 2018 tersebut menunjukkan bahwa pengaruh net profit margin terhadap harga saham pada perusahaan manufaktur sektor industri barang konsumsi yang terdaftar di BEl periode tahun 2013-2016 dapat dilihat pada tabel 4 berikut.

Tabel 4. Hasil Uji Signifikan Parsial (Uji t)

\begin{tabular}{cccccc}
\hline \multirow{2}{*}{ Model } & \multicolumn{2}{c}{$\begin{array}{c}\text { Unstandardized } \\
\text { Coefficientd }\end{array}$} & $\begin{array}{c}\text { Standarized } \\
\text { Coefficients }\end{array}$ & t & Sig. \\
\cline { 2 - 4 } & $\mathrm{B}$ & Std. Error & Beta & & \\
\hline 1 (Constant) & -47203 & 9591 & & -4922 & 0.000 \\
\cline { 2 - 4 } $\begin{array}{c}\text { Net profit } \\
\text { margin }\end{array}$ & 203505 & 69175 & 0.302 & 2.942 & 0.005 \\
\hline
\end{tabular}

\section{Pengaruh net profit margin} terhadap harga saham pada perusahaan manufaktur sektor industri barang konsumsi berdasarkan perhitungan uji $t$ pada tabel 4 menunjukkan bahwa net profit margin berpengaruh terhadap harga saham pada perusahaan manufaktur sektor industri barang konsumsi, karena variabel Net Profit Margin memiliki $p$ value $=0,005<\alpha=0,05$ maka $\mathrm{H}_{0}=$ ditolak dan $\mathrm{H}_{\mathrm{a}}$ diterima. Dengan demikian dapat disimpulkan bahwa Net Profit Margin memiliki pengaruh yang positif dan signifikan terhadap harga saham pada perusahaan manufaktur sektor industri barang konsumsi.

Pengaruh secara simultan current ratio, dept to equiy, return on equity dan net profit margin terhadap harga saham pada perusahaan manufaktur sektor industri barang konsumsi yang terdaftar di Bursa Efek Indonesia. Untuk mengetahui pengaruh secara simultan current ratio, debt to equity, return on equity dan net profit margin terhadap harga saham pada perusahaan manufaktur sektor industri barang konsumsi dilakukan dengan menggunakan uji satistik $F$ dengan program SPSS 17.0 for windows. Uji statistik $F$ ini menunjukkan semua variabel bebas yaitu current ratio (X1), debt to equity (X2), return on equity (X3), dan net profit margin (X4) dimasukkan ke dalam model yang mempunyai pengaruh terhadap variabel terikat yaitu harga saham $(\mathrm{Y})$. Hasil uji statistic $\mathrm{F}$ tersebut diperoleh hasil seperti terlihat pada tabel 5 berikut.

Tabel 5. Hasil Uji Statistik Simultan (Uji F)

\begin{tabular}{|c|c|c|c|c|c|c|}
\hline & Model & $\begin{array}{l}\text { Sum of } \\
\text { Squares }\end{array}$ & & & & \\
\hline 1 & Regression & 63.163 .872 .810 & 4 & 15.790 .968 .202 & 33.379 & $.000^{\mathrm{a}}$ \\
\hline & Residual & 24.127 .437 .539 & 51 & 473.087 .011 & & \\
\hline & Total & 87.291 .310 .348 & 55 & & & \\
\hline
\end{tabular}

Berdasarkan hasil analisis uji satistik $F$ pada tabel 5 menunjukkan bahwa $p$-value $=0,000<\alpha=0,05$ berarti $\mathrm{H}_{0}=$ ditolak dan $\mathrm{H}_{\mathrm{a}}$ diterima. Jadi dapat disimpulkan bahwa current ratio (X1), debt to equity (X2), return on equity (X3), dan net profit margin (X4) memiliki pengaruh yang signifikan secara simultan terhadap harga saham (Y). Hal ini dibuktikan melalui hasil analisis regresi linier berganda yang menunjukkan bahwa current ratio, dept to equity, return on equity dan net profit margin memiliki pengaruh yang signifikan terhadap harga saham pada perusahaan manufaktur sektor industri barang konsumsi yang terdaftar di bei periode tahun 2013-2016. Untuk mengetahui besarnya pengaruh bahwa current ratio, debt to equity, return on equity, dan net profit margin memiliki pengaruh yang signifikan secara simultan terhadap harga saham pada perusahaan manufaktur sektor industri pada perusahaan manufaktur sektor industri barang konsumsi yang terdaftar di BEI periode tahun 2013-2016, maka dapat digunakan analisis koefisien 
p-ISSN : $2599-1418$

e-ISSN : 2599-1426
Jurnal Pendidikan Ekonomi Undiksha

Volume 10 No. 2 Tahun 2018 determinasi (Adjusted $R$ Square).

Besarnya koefisien determinasi
(Adjusted $R$ Square) dapat dilihat pada tabel

berikut.

Tabel 6. Hasil Perhitungan Koefisien Determinasi (Adjusted $R$ Square)

\begin{tabular}{|c|c|c|c|c|}
\hline Model & $\mathrm{R}$ & R Square & $\begin{array}{l}\text { Adjusted R } \\
\text { Square }\end{array}$ & $\begin{array}{l}\text { Std. Error of } \\
\text { the Estimate }\end{array}$ \\
\hline 1 & $.851^{\mathrm{a}}$ & 0.724 & 0.702 & 21.750 .56345 \\
\hline
\end{tabular}

Berdasarkan hasil analisis pada tabel 6 dengan menggunakan SPSS 17.0 for windows menunjukkan bahwa besarnya Adjusted $R$ Square adalah 0,702 , hal ini berarti $70,2 \%$ harga saham $(\mathrm{Y})$ dipengaruhi secara simultan oleh current ratio (X1), debt to equity (X2), return on equity (X3), dan net profit margin (X4), sedangkan sisanya $20,8 \%$ dipengaruhi oleh faktor lain yang tidak termasuk dalam penelitian ini.

\section{Pembahasan}

Pengaruh current ratio terhadap harga saham pada perusahaan manufaktur sektor industri barang konsumsi yang terdaftar di Bursa Efek Indonesia (BEI). Berdasarkan hasil olahan data pada hasil pembahasan di atas, maka dapat diketahui bahwa current ratio berpengaruh positif dan signifikan terhadap harga saham pada perusahaan manufaktur sektor industri barang konsumsi yang terdaftar di BEI. Tinggi rendahnya current ratio pada suatu perusahaan dilihat dari kemampuan perusahaan memenuhi jangka pendeknya. Sesuai dengan pendapat Fahmi (2001:140) yang menyatakan, current ratio bagian dari rasio likuiditas merupakan kemampuan suatu perusahaan memenuhi kewajiban jangka pendeknya secara tepat waktu. Current ratio menunjukkan sejauh mana aktiva lancar menutupi kewajibankewajiban lancar. Semakin besar perbandingan aktiva lancar semakin tinggi kemampuan perusahaan menutupi kewajiban jangka pendeknya dan sebaliknya semakin rendah nilai current ratio menunjukkan terjadi masalah likuidasi. Semakin besar nilai current ratio menunjukkan bahwa perusahaan memiliki kemampuan dalam memenuhi kebutuhan operasionalnya terutama modal kerja yang sangat penting untuk menjaga performance perusahaan yang pada akhirnya mempengaruhi harga saham. Hal ini dapat memberikan keyakinan kepada investor untuk membeli saham perusahaan sehingga harga saham meningkat.

Pengaruh dept to equity terhadap harga saham pada perusahaan manufaktur sektor industri barang konsumsi yang terdaftar di Bursa Efek Indonesia (BEI). Berdasarkan hasil olahan data pada hasil pembahasan di atas, maka dapat diketahui debt to equity berpengaruh positif dan signifikan terhadap harga saham pada perusahaan manufaktur sektor industri barang konsumsi di BEl. Hipotesis kedua debt to equity berpengaruh secara signifikan terhadap harga saham diterima yang menggambarkan sejauh mana modal pemilik dapat menutupi hutang-hutang kepada pihak luar dan mengukur hingga sejauh mana perusahaan dibiayai hutang. Sesuai dengan teori dari Sawir (2001:13) yang menyatakan, semakin tinggi debt to equity artinya semakin tinggi pula tanggungan perusahaan terhadap pihak ketiga (kreditur) sehingga ketika perusahaan memperoleh laba maka perusahaan akan menggunakan laba tersebut untuk membayar bunga utang atau utang dan otomatis akan mempengaruhi deviden yang diterima investor. Investor mungkin akan berfikir untuk tidak menanamkan modalnya pada perusahaan yang memiliki banyak hutang, pastinya akan mempengaruhi naik turunnya harga saham perusahaan. Sebagian kecil investor memamdang bahwa perusahaan yang tumbuh akan memerlukan banyak dana operasi yang tidak mungkin dapat dipenuhi dari modal sendiri dan pasti akan memerlukan dana dari pihak 
p-ISSN : 2599-1418

e-ISSN : 2599-1426

ketiga (kreditur). Jadi disini sebagian investor akan membeli saham yang memiliki nilai debt to equity tinggi karena perusahaan sedang berada dalam masa pertumbuhan, dan akan mempengaruhi harga saham.

Pengaruh return on equity terhadap harga saham pada perusahaan manufaktur sektor industri barang konsumsi yang terdaftar di Bursa Efek Indonesia (BEI). Berdasarkan hasil olahan data pada hasil pembahasan di atas, maka dapat dikertahui bahwa return on equity berpengaruh positif dan signifikan terhadap harga saham pada perusahaan manufaktur sektor industri barang konsumsi yang terdaftar di BEI. Tinggi rendahnya return on equity akan membawa dampak mengenai ketertarikan minat investor dalam menanamkan modalnya dengan harapan yang akan mendapatkan keuntungan yang tinggi. Sesuai dengan pendapat dari Irawati (2006:94) yang menyatakan, semakin besar rasionya semakin bagus karena dianggap kemampuan perusahaan yang efektif dalam menggunakan ekuitasnya untuk menghasilkan laba. Rentabilitas modal sendiri memperlihatkan sejauh manakah perusahaan mengelola modal sendiri secara efektif dan mengukur tingkat keuntungan dari investasi yang telah dilakukan pemilik modal sendiri atau pemegang saham perusahaan. Semakin tinggi return on equity menunjukkan bahwa semakin baik kinerja keuangan perusahaan dalam memperoleh laba dan juga akan mempengaruhi pemberian deviden kepada investor untuk membeli saham perusahaan tersebut dan berimbas pada kenaikan harga saham.

Pengaruh net profit margin
terhadap harga saham pada
perusahaan manufaktur sektor industri barang konsumsi yang terdaftar di Bursa Efek Indonesia (BEI). Berdasarkan hasil olahan data pada hasil pembahasan di atas, maka dapat dikertahui bahwa net profit margin berpengaruh positif dan signifikan terhadap harga saham pada perusahaan manufaktur sektor industri
Jurnal Pendidikan Ekonomi Undiksha

Volume 10 No. 2 Tahun 2018

barang konsumsi yang terdaftar di BEl. Tipe industri dengan konsumen yang memiliki loyalitas terhadap produk perusahaan sehingga menciptakan kondisi pasar yang stabil. Kondisi pasar yang stabil membuat industri barang konsumsi dapat melaksanakan kegiatan operasional perusahaan dengan baik sehingga perusahaan dapat mencapai tingkat efisiensi yang tinggi. Sesuai dengan pendapat dari Irawati (2006:95) yang menyatakan, semakin tinggi nilai margin laba bersihnya maka dipastikan perusahaan semakin efisiensi dalam mengelola biaya-biaya terkait operasional perusahaan. Dengan demikian pelaku pasar modal akan memberikan tanggapan yang positif, dimana investor akan lebih tertarik untuk menanamkan modalnya pada peusahaan tersebut karena dianggap mampu menghasilkan net income dari kegiatan operasi pokoknya. Dengan kata lain, semakin besar net profit margin suatu perusahaan maka semakin besar pula harga sahamnya.

Pengaruh simultan current ratio, dept to equiy, return on equity dan net profit margin terhadap harga saham pada perusahaan manufaktur sektor industri barang konsumsi. Berdasarkan hasil olahan data pada hasil pembahasan di atas mengenai pengaruh current ratio, debt to equity, return on equity dan net profit margin terhadap harga saham pada perusahaan manufaktur sektor industri barang konsumsi yang terdaftar di bursa efek Indonesia, dapat diketahui bahwa current ratio, debt to equity, return on equity dan net profit margin semakin baik rasio keuangan perusahaan maka semakin baik pula kinerja perusahaan yang pada akhirnya mempengaruhi harga saham, dapat memberi keyakinan pada investor keuangan yang baik sehingga akan dapat meningkatkan harga saham perusahaan. Pembuktiannya melalui hasil analisis regresi linear berganda yang menunjukkan bahwa current ratio, debt to equity, return on equity dan net profit margin memiliki pengaruh simultan secara signifikan terhadap 
p-ISSN : 2599-1418

e-ISSN : 2599-1426
Jurnal Pendidikan Ekonomi Undiksha

Volume 10 No. 2 Tahun 2018 harga saham pada perusahaan manufaktur sektor industri barang konsumsi yang terdaftar di BEI periode tahun 2013-2016 Adjusted $R$ Square adalah 0,702, hal ini berarti $70,2 \%$ harga saham (Y) dipengaruhi secara simultan oleh current ratio (X1), debt to equity (X2), return on equity (X3), dan net profit margin (X4), sedangkan sisanya $20,8 \%$ dipengaruhi oleh faktor lain yang tidak termasuk dalam penelitian ini. Penelitian sejalan dengan hasil penelitian terdahulu yang dilakukan Suyoga (2013) bahwa eraning per share, price earning ratio, return on equity terhadap harga saham pada perusahaan sektor telekomunikasi yang terdaftar di Bursa Efek Indonesia.

\section{SIMPULAN DAN SARAN Simpulan}

Berdasarkan hasil analisis data, maka dapat di buat simpulan variabel bebas current ratio mempunyai pengaruh yang signifikan terhadap harga saham pada perusahaan manufaktur sektor industri barang konsumsi yang terdaftar di Bursa Efek Indonesia periode 2013-2016. Hal ini ditunjukkan dari tingkat signifikansi $\mathrm{X}_{1}$ (Current Ratio) sebesar $0,003<0,05$, variabel bebas dept to equity mempunyai pengaruh yang signifikan terhadap harga saham pada perusahaan manufaktur sektor industry barang konsumsi yang terdaftar di Bursa Efek Indonesia periode 20132016. Hal ini ditunjukkan dari tingkat signifikansi $\mathrm{X}_{2}$ (Dept to Equity) sebesar $0,004<0,05$, variabel bebas return on equity mempunyai pengaruh yang signifikan terhadap harga saham pada perusahaan manufaktur sektor industry barang konsumsi yang terdaftar di Bursa Efek Indonesia periode 20132016. Tingkat signifikansi $X_{3}$ (Return on Equity) sebesar 0,006<0,05, variabel bebas net profit margin mempunyai pengaruh yang signifikan terhadap harga saham pada perusahaan manufaktur sektor industri barang konsumsi yang terdaftar di Bursa Efek Indonesia periode 2013-2016. Hal ini ditunjukkan dari tingkat signifikansi $\mathrm{X}_{4}$
(Net profit Margin) sebesar 0,005<0,05 dan hasil penelitian menunjukkan bahwa secara simultan seluruh variabel bebas (Current ratio, dept to equity, return on equity, dan net profit margin) memiliki pengaruh yang signifikan terhadap harga saham pada perusahaan manufaktur sektor industri barang konsumsi yang terdaftar di Bursa Efek Indonesia periode 20132016. Hal tersebut ditunjukkan oleh besarnya nilai sig. $\mathrm{F}_{\text {hitung yaitu }}$ $0,000<0,05$.

\section{Saran}

Berdasarkan simpulan, maka dapat dikemukakan beberapa saran yaitu bagi pelaku pasar modal khususnya investor di dalam melakukan investasi jangka panjang terlebih dahulu perlu menjadikan kinerja keuangan perusahaan sebagai bahan pertimbangan sebelum melakukan investasi seperti current ratio, dept to equity, return on equity, dan net profit margin, dan bagi akademik sebaiknya jumlah sampel yang dipilih diperbanyak dengan memikirkan keterwakilan semua kelompok industri serta periode pengamatan yang lebih panjang. Dengan demikian hasil peneliti yang diperoleh akan lebih baik. Peneliti selanjutnya ada baiknya untuk mempertimbangkan jenis rasio yang lebih beragam dalam artian bisa mewakili masing-masing rasio yang ada.

\section{DAFTAR PUSTAKA}

Alwi, Iskandar. 2003. Pasar Modal Teori dan Aplikasi. Jakarta: Nasindo Indonesia.

Fahmi, Irham. 2001. Analisis Kinerja Keuangan. Bandung: ALFABETA.

Gitman. 2008. Manajemen Keuangan. Jakarta: PT. Raja Grasindo Aksara.

Halim, Abdul. 2005. Analisis Investasi. Jakarta: Selemba Empat.

Harahap, Sofyan Syafri. 2008. Analisis Kritis Atas Laporan Keuangan. Jakarta: PT. Raja Grasindo Aksara. 
Husnan, Suad. 2003. Manajemen Perbankan. Bandung: PT. Gramedia Pustaka Utama.

Irawati. 2006. Manajemen Keuangan. Cetakan ke-1. Bandung: PT. Pusaka.

Kasmir. 2008. Manajemen Perbankan, Edisi Revisi 2008. Jakarta: PT. Raja Grafindo Persada

------. 2012. Bank dan Lembaga Keuangan Lainnya. Jakarta: PT. Raja Grafindo Persada,

Nirawati. 2003. Pasar Modal dan Manajemen Portofolio. Jakarta: Erlangga.

Rahmadi, Latif. 2010. Pengaruh Kinerja Keuangan terhadap Harga Saham pada Perusahaan Perbankan yang Terdaftar di Bursa Efek Indonesia Periode 2004-2008. Skripsi (diterbitkan). Yogyakarta: Universitas Negeri Yogyakarta.

Sawir, Agnes. 2001. Analisis Kinerja Keuangan dan Perencanaan Keuangan Perusahaan. Jakarta: PT. Gramedia Pustaka Utama.

Subramanyam. 2005. Analisis laporan Keuangan. Jakarta: Salemba Empat.

Susilo D, Bambang. 2009. Pasar modal Mekanisme Perdagangan Saham Analisis Sekuritas dan Strategi Investasi Di Bursa Eek Indonesia. Yogyakarta: UPP STIM YKPN.

Suyoga, Ngurah. 2013. Pengaruh Variabel Earning Per Share (EPS), Price Earning Ratio (PER), Return On Equity (ROE), terhadap Harga Saham Pada Perusahaan Sektor Telekomunikasi yang terdaftar di PT. Bursa Efek Indonesia. Skripsi (diterbitkan). Denpasar: Universitas Warmadewa. 